\title{
水素処理した $\mathrm{MoO}_{3}-\mathrm{Al}_{2} \mathrm{O}_{3}$ 触媒による 1 -プテンの 異性化および水素化
}

(1977 年 7 月 1 日受理)

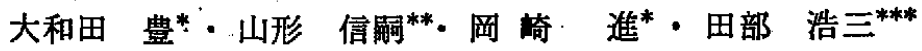

\begin{abstract}
水素处理した $\mathrm{MoO}_{3}-\mathrm{Al}_{2} \mathrm{O}_{3}$ 触媒上で1ーブテンの異性化および东素化反応を行ない，その触媒活性に 対する蜰媒処理の影響について検討した。反応は, 通常の流通法を用いて, $\mathrm{H}_{2}$ あるいは $\mathrm{H}_{2} \mathrm{~S} て ゙$ 前処 理したのち，ただちに窒素あるい性水素気流中で行なった。

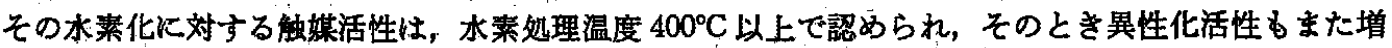

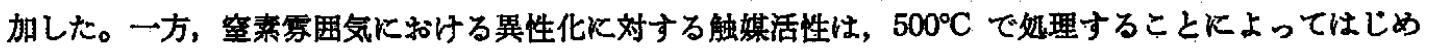
て, 未処理の触媒活性より高くなった。水およびトリエチルアミンを反忘中に徽量添加した結果, 前者 は可逆的に，後者は不可逆的に被毒した。しかしながら，二酸化炭素では被者されなかった。上の反応 に対する触媒活性を他の゙ブテン異性体のそれと比較したところ, 異性化はいずれのブテンにおいている ぼ平衡転化率まで進行したのに対し，氷素化に対しては trans-2-ブテン>1ーブテン》cis-2-ブテン の瀬になり，..選択性が認められた。

塩基性試莱によって被毒されるという結果から，両反応の活性点は，ともに電子受容体であると考え られだしかしながら，ブテシの異性体間で，雨反応江奶して反応性が翼なるため，これらの活性点は それどれ異なることが示唆された。

さらに，触媒の性質を明がするために，2-プロパノールの分解反応についても試み，これらの触媒 作用と水素めるいは硫化水素処理された $\mathrm{MoO}_{3}-\mathrm{Al}_{2} \mathrm{O}_{3}$ 繦媒の表面構造との関俰を検討した。
\end{abstract}

\section{1. 粕言}

较化モリブデン(U)をアルミナと含漫担持した $\mathrm{MoO}_{3}-\mathrm{Al}_{2} \mathrm{O}_{3}$ 触

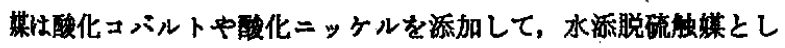
て広籍に使用され、これに関する研究は数多い。ESR")めるいは 水来复元速度の湖起2などの結果から，アルミナと担持した酸化 モリブデン $(\mathrm{N})$ がその表面炕単分子層を形成し，分散性の高い状 暗炕あること，さらK，水素あるい怡硫化水慗处理によってでき る表面の構造などが明らがされてきた。また，水素処理した $\mathrm{MoO}_{3}-\mathrm{Al}_{2} \mathrm{O}_{3}$ 触媒がピりジンなぞの塩基性気体を不可逆的に吸着

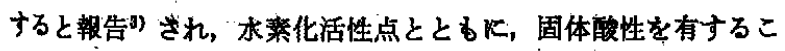
とが示唆された。しかしながら、こうした活性点と触媒作用との

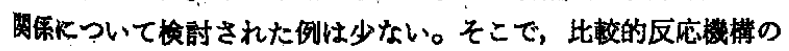
よく知られた 1ーブテンの異性化扰よび水秦化反応を取りあげ,

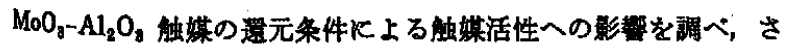

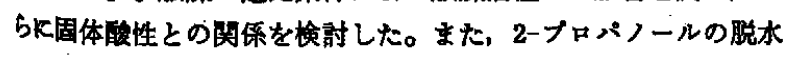

* 茨城大学工学部工業化学科, 316 日立市中成沢町

** 芙城工業高等専門学校工前化学科，312 勝田市中㮛

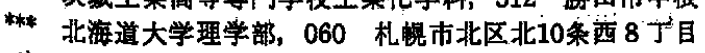

1) M. Dufaux, M.Ch.C.Naccache, J.Chim. Phys., 67, 527 (1970)；加部利明，触某，15，170(1973).

2) F. E. Massoth, J. Catal., 30, 204(1973).

3）山田谷正子，加部利明，大場晶明，三术康期，日化，1972， 227.
および脱水菜反応についてす行ない、これらの結果をむとに, 最 近昭らかにされた $\mathrm{MoO}_{3}-\mathrm{Al}_{2} \mathrm{O}_{3}$ 触媒の表面状熊との関連を考察 した。

\section{2 実駼}

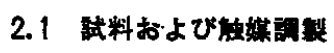

反応に用いた1-ブテン, cis-2-ブテン, trans-2-ブテン，およ び 2-ブッパールは，いずれも純度 99\%以上の市肘品を直接使 用した。

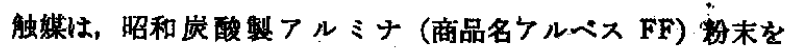
$500{ }^{\circ} \mathrm{C}$ で 3 洔間電気炉中で前焼成し，これに䓄定量のバラモリブ デン酸アンモニウム（関東化学試薬特級）水溶液仁 2 日間浸清担 持したのち， $120^{\circ} \mathrm{C} て ゙ 6$ 時間蒸発䢀固して調製した。反応に供す

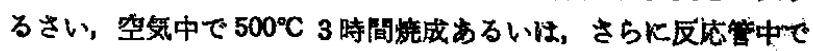
200 ないし $500^{\circ} \mathrm{C} て ゙ 2$ 時間水莱处理した。水莱流量は每分 $150 \mathrm{ml}$ とした。

\section{2 反必装置およひ生成物の分析}

ブテンの異性化および水莱化は, 通常の流通式固定床反応器を

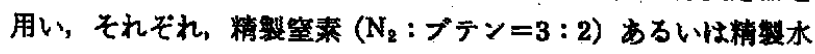
糸 $\left(\mathrm{H}_{2}:\right.$ ブテン=3:1）の祭司気で行なった。触媒量は 2 ないし $3 \mathrm{~g}$ とし，混合䍊体の流量を变化させ触媒活性を湘定した。区応 生成物は，異性化による cisーおよび trans-2-ブテン，水乗化に よるブタンで，骨格異性化によるインブチレンあるい忹不均化や 
酸化反応によると考劣られる生成物は認められなかった。生成物 の分離に绀ガスクロ工業製 VZ-7 を充てん刘とする銅カラム 7 m を使用した。

\section{3 アンモニア溶出实験}

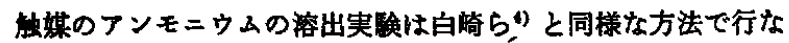
い，触媒中の未溶出酸化モリブデン量を決定した。定量には日本 ジャレルアッシュ社製原子吸光光度䛨を使用した。

\section{3 結 果}

\section{$3.1 \mathrm{MoO}_{3}-\mathrm{Al}_{2} \mathrm{O}_{3}$ 触媒による 1-ブテンの異性化と固体酸性}

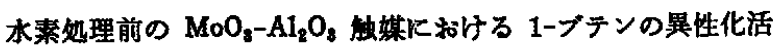
性および酸化モりブデン(口)の担持量の影算を把㩧するために， 反応温度 $150^{\circ} \mathrm{C}$, 窒素気流中で反応を行なった。2-プテンへの異 性化速度は見かけ一次反応速度式によって近似することができた。 因 1 K酸化モりブデンの担持量飞対する速度定数および trans2-ブテンk対する cis-2-プテンの生成比（以下 cis-/trans-と略 钎する)を示した。なお生成比は各接触時間代和ける cis-/trasn一 のブロットを転化率0飞外掩して求めた。また， $\mathrm{MoO}_{3}-\mathrm{Al}_{2} \mathrm{O}_{3}$ 触 媒の能性度战よび比表面穔る示した（因 1-(b))。图加らかかる

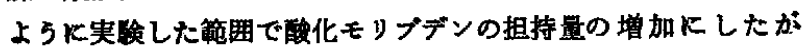

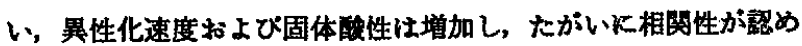
られるす)。

一方，0転化率の cis-/trans- は, アルミナ担体の 2.8 から， 酸化モリブデン(U)量增加にとるない1.8へと变化した。フリル フニオン中間体を経て進行するフルミナやマグネシフでは, cis-1

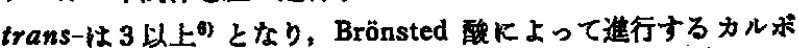

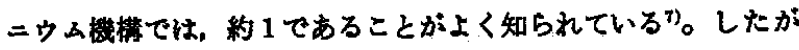
って $\mathrm{MoO}_{3}-\mathrm{Al}_{2} \mathrm{O}_{3}$ 触媒の cis-/trans- はそれぞれの中間俌とい える。

\section{$3.2 \mathrm{MoO}_{3}-\mathrm{Al}_{2} \mathrm{O}_{3}$ 波媒の水来処理温度の影䇺}

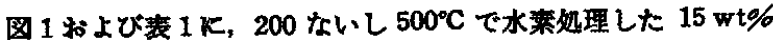

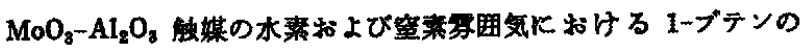
水素化叔よび異性化反応の触媒活性を示した。反応は，その開始 初期にいらしるしい活性低下が見られたが，汪活 2 時間後定常 活性に逢したので 2 時間以降の異性化速度を澌定し，一次反応速 度定数を求的た。っかし；水菜化速度を単納似一次式飞近似させ ることができなかったので，W/F=28.0 g/hr/mol の値を水素化 活性の代装值とした。

図 2 の結果では，水秦処理温度 $400^{\circ} \mathrm{C}$ から水素化活性が認めら れ，異性化活牲るこれに対応して增加している。とくに $500^{\circ} \mathrm{C}$ 処 理の場合にはその影繁が大を，異性化活性は $400^{\circ} \mathrm{C}$ の域合とく らへ約 4 倍飞，本来化活性恃 $2 \%$ から $28 \%$ へと增加している。 $300^{\circ} \mathrm{C}$ 以下の水菜处理では処理効果がまったく琵められない。こ のよろな300ないし $400^{\circ} \mathrm{C}$ Kかけての处理温度によろ変化怯, 酸 化モリブデン(И)のフンモニフ水溶液への溶出量飞も見られる

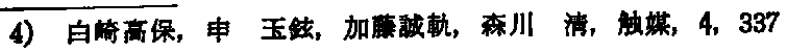
(1962).

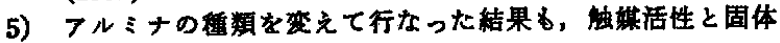
酸性度との閶火相関性が詪められた。

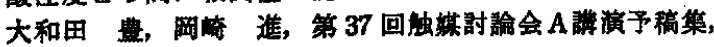
p. 88(1975).

6) 田部浩三，腜媒，17，32(1975).

7) 田部浩三，“触媒の恃たらき”，化学间人 (1974) p. 21.

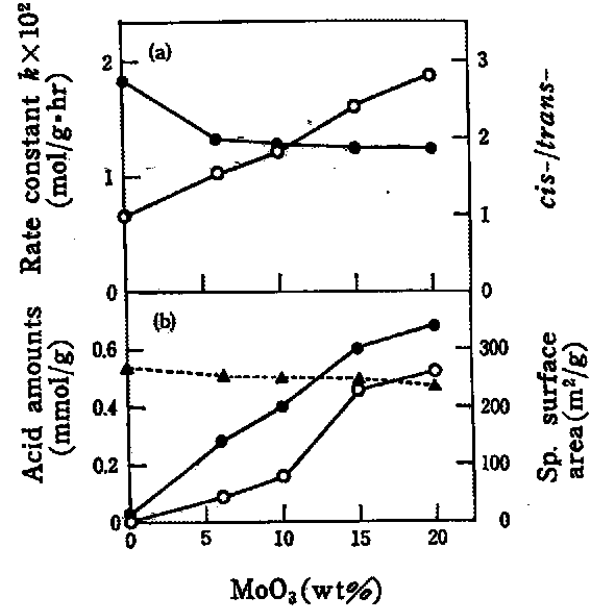

Fig. 1 The catalytic activity for isomerization of 1-butene, the acidity and specific surface area on $\mathrm{MoO}_{3}-\mathrm{Al}_{2} \mathrm{O}_{3}$ before pretreatment

(a) -O-: Rate constant for isomerization - - : Selectivity of cis- to trans-2-butene

(b) $-\mathrm{O}-,-\mathrm{O}-$ : The acidity at $H_{0}<+3.3$ and +4.8 , respectively

- -A- - : Specific surface area

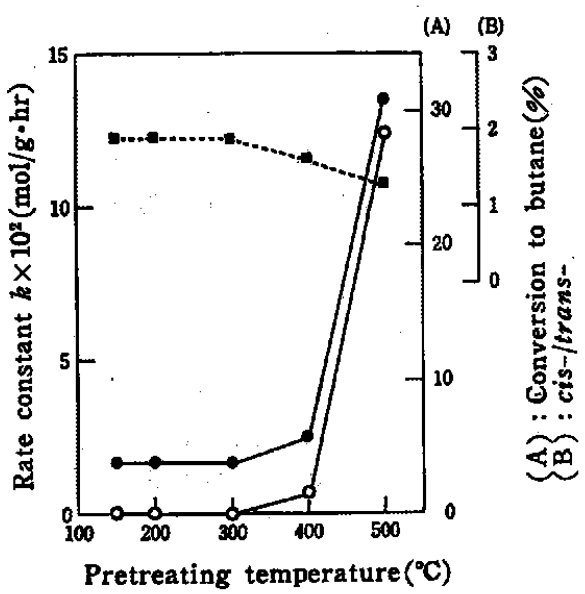

Fig. 2 Effect of the pretreating temperature on the catalytic activity for hydrogenation of 1-butene

Catalyst : 15 wt $\% \mathrm{MoO}_{3}-\mathrm{Al}_{2} \mathrm{O}_{3}$

Reaction temperature : $150^{\circ} \mathrm{C}$, in $\mathrm{H}_{2}$ atmosphere

: Rate constant of isomerization

: Selectivity of cis- to trans-2-butene

$O$ : Conversion to butane at $28.0 \mathrm{~g} \cdot \mathrm{hr} / \mathrm{mol}$ in $W / F$

Table 1 Effect of pretreating temperature on the catalytic activity for isomerization of 1butene

\begin{tabular}{ccc}
$\begin{array}{c}\text { Pretreatment } \\
\text { temperature }\left({ }^{\circ} \mathrm{C}\right)\end{array}$ & $\begin{array}{c}\text { Rate constant } \\
k \times 10^{2}(\mathrm{~mol} / \mathrm{g} \cdot \mathrm{hr})\end{array}$ & cis-/trans- \\
\hline 150 & 1.5 & 1.8 \\
300 & 1.1 & 1.8 \\
400 & 1.1 & 1.8 \\
500 & 3.2 & 1.3
\end{tabular}

Reaction temperature : $150^{\circ} \mathrm{C}$ in $\mathrm{N}_{2}$ atmosphere. 


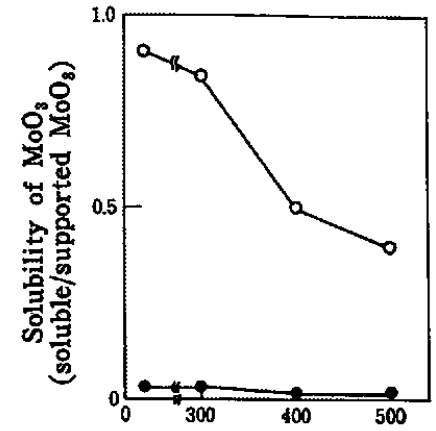

Pretreating temperature $\left({ }^{\circ} \mathrm{C}\right)$

Fig. 3 The solubility of $\mathrm{MoO}_{3}$ in water and ammonia water vs. pretreating temperature

: In water

$0:$ In $3 \mathrm{~N}$ ammonia water

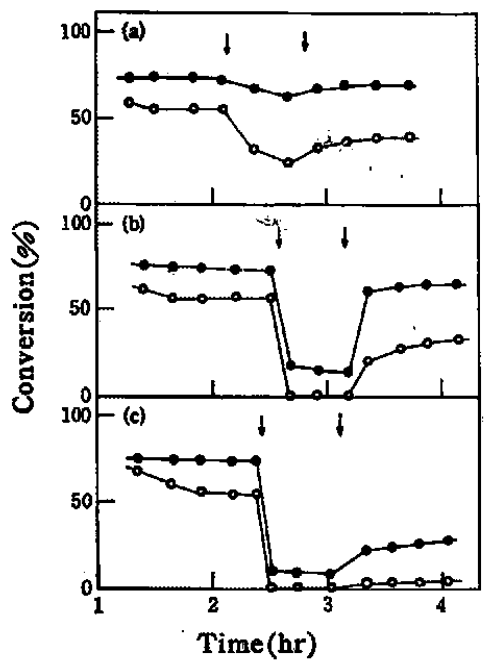

Fig, 4 Effect of poisoning with $\mathrm{CO}_{2}, \mathrm{H}_{2} \mathrm{O}$ and triethylamine

Catalyst : 15 wt\% $\mathrm{MoO}_{3}-\mathrm{Al}_{2} \mathrm{O}_{3}$ pretreated with $\mathrm{H}_{2}$ at $450^{\circ} \mathrm{C}$, Reaction temperature : $200^{\circ} \mathrm{C}$

$W / F: 12.5 \mathrm{~g} \cdot \mathrm{hr} / \mathrm{mol}$

(a) : Poisoning with $\mathrm{CO}_{2}$, (b) : $\mathrm{H}_{2} \mathrm{O}$, (c) : Triethylamine

: Conversion to 2-butenes (2-butenes/butenes)

$O:$ Conversion to butane (butane/butenes and butane)

(图3)。すなから，この温度簀囲で溶出量が 85 から50\%に減少 している。酸化モリブデンの溶解度は酸化状態によって異なるる ため, この変化は $350^{\circ} \mathrm{C}$ 前後から担持した酸化モリブデン(И)が より低原子洒の酸化状態に還元されたことを示している。

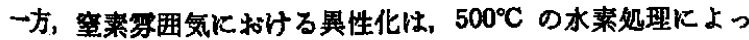
て、初めてその影鳘が現われる。しかしながら，その影银は水素

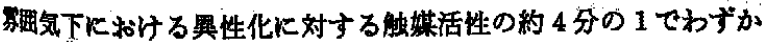

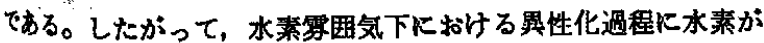
数していることは明かである。

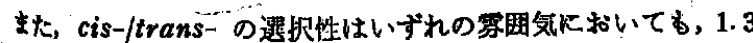

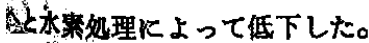

8) 酸化モりブデン(N)性，酸化モンブデン(V)よりアンモ= ア水溶液に対寸る溶解度が低い。
Table 2 Steric effect on hydrogenation of butenes Catalyst : $15 \mathrm{wt} \% \mathrm{MOO}_{3}-\mathrm{Al}_{2} \mathrm{O}_{2}$ pretreated with $\mathrm{H}_{2}$ at $400^{\circ} \mathrm{C}$

Reaction temperature : $200^{\circ} \mathrm{C}$ $W / F: 12.5 \mathrm{~g} \cdot \mathrm{hr} / \mathrm{mol}$

\begin{tabular}{lccc} 
& $\begin{array}{c}\text { Total convresion } \\
(\%)\end{array}$ & $\begin{array}{c}\text { Other isomers } \\
(\%)\end{array}$ & $\begin{array}{c}\text { Butane } \\
(\%)\end{array}$ \\
\hline 1-Butane & 79.5 & 77.5 & 9.9 \\
cis-2-Butene & 63.9 & 69.0 & 2.7 \\
trans-2-Butene & 50.5 & 43.9 & 11.8
\end{tabular}

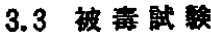

$450^{\circ} \mathrm{C}$ で水素処理 $た \mathrm{MoO}_{3}-\mathrm{Al}_{2} \mathrm{O}_{3}$ 触蝶による 1-ブテンの水

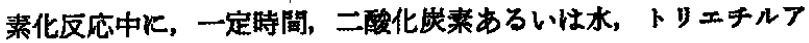
ミンを注入し、その触媒活性变化を調べた。その結果を図 4 k示 †。

まず，二醉化炭素を $41.7 \mathrm{mmol} / \mathrm{hr}$ の速度で添加すると活性が 若干低下する。しかしながら，その低下の程度が小さく、反応気 体の分压低下下よるるのか，あるい性二酸化炭素中の不糺物比よ るすの之考光られ，本質的な被毒でない。一方，水またはトリエ チルアミンの微量添加によっていちしるしく 2-ブテンへの活性 が低下し,ブタンへの活性は消失した。このときの触媒 $1 \mathrm{~g}$ あた りの水和よびトリエチルフミンの注入量は，それぞれ 7,0.9

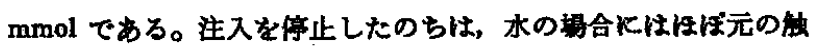
婪活性火回復するのに対し，トソエチルフミンで性，2-プテンヘ の云化率が 30\%，ブタンへの枟化率仕 10\% まで回復するにすぎ ない。すなわち，後者が一部不可巡的にこれらの活性点炕昨着し たことを示す。

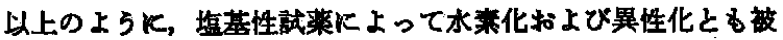
藤されるといらことから，少なくともこれらの活性点が電子受容 体であるらと考えられる。

\section{4 trans- および cis-2-フテンンの水東化}

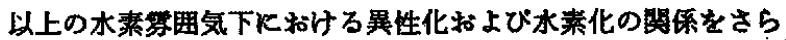
に明らかにするために，異性化生成物である cis-おおよび trans2-プテンの水秦化を 1-ブテンの場合と条件を同しくして行なっ た。その結果を表 2 に示す。

1-ブテン, cis- お゙よ゙ trans-2-ブテンの異性化反応に和ける 平衙伝化率は，それぞれ 86.4，70.1，43.5\% である”。したが って表 2 の各異性体の異性化転化率は，いずれあはとんど平鹪に 羊していると孝えられる。

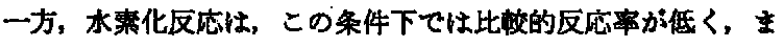
た trans-2-ブテン>1-ブテン》cis-2-プテンの頪低下し選

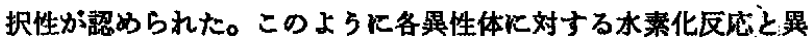
性化反矿とが，その㑯向に拈いてまったく翼なっていることがか かる。同梾な触媒を用いたクメンの水秦化分解化执いてる，その とき起こる巽性化と水素化汶対する反応性が大きく異なると報 告10)され，これらのことから，異性化活性点と水素化活性点とは たがいК簧なるすのと推定される。

\subsection{2-プロパールの脱水および脱水絭反応}

2ープロパノールの脱水および脱水素反応汇対する種々の条件で

9) E. F. Meyer, D. G. Stroz, J. Am.Chem. Soc., 74, 6344 (1972).

10）三木康䬣，山田谷正子，加部利明，大揭岛明，日化，1975, 771. 
Table 3 The catalytic activity for dehydration and dehydrogenation of 2-propanol

\begin{tabular}{ccccc}
$\begin{array}{c}\text { Catalyst } \\
\text { treating } \\
\text { temperature }\end{array}$ & $\begin{array}{c}\text { Total } \\
\text { conversion } \\
(\%)\end{array}$ & $\begin{array}{c}\text { Propylene } \\
(\%)\end{array}$ & $\begin{array}{c}\text { Diisopropyl } \\
\text { ether } \\
(\%)\end{array}$ & $\begin{array}{c}\text { Acetone } \\
(\%)\end{array}$ \\
\hline $\mathrm{Al}_{8} \mathrm{O}_{8}$ & 46.2 & 40.1 & 6.1 & 0 \\
$\mathrm{MoO}_{8}-\mathrm{Al}_{2} \mathrm{O}_{3}$ & 54.4 & 47.9 & 5.0 & 1.5 \\
$400^{\circ} \mathrm{C}$ & 55.7 & 47.9 & 5.0 & 2.6 \\
$500^{\circ} \mathrm{C}$ & 57.3 & 44.4 & 6.3 & 6.6 \\
$\mathrm{MoO}_{8}-\mathrm{Al}_{2} \mathrm{O}_{8}-\mathrm{H}_{2} \mathrm{~S}^{a)}$ & 67.3 & 38.2 & 3.6 & 25.5
\end{tabular}
$450^{\circ} \mathrm{C}$

Reaction temperature $: 220^{\circ} \mathrm{C}, W / F: 7.5 \mathrm{~g} \cdot \mathrm{hr} / \mathrm{mol}$

a) The catalyst was pretreated with hydrogen sulfide and hydrogen. Hydrogen sulfide was feeded at $0.05 \mathrm{~mol} / \mathrm{hr}$.

処理を旗した 15 wt\% $\mathrm{MoO}_{8}-\mathrm{Al}_{2} \mathrm{O}_{3}$ 触媒の蚛媒活性の結果を衰 3 に示す。この反応は，脱水に上ってブロピレンおよびジンブロ ピルエーテルを生成し，眖水素によってアセトンが生成する。前

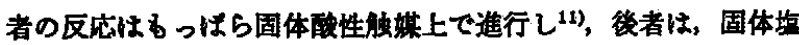
基するい恃金属䖽集上て促進されることがよく知られている12)。 表 3 飞示されるよう下脱水素活性は水秦处理温度に依存し, 高温 処理注ど急激に高くなる傾向にあり，1-ブテンの水素化之類倒し ている。これに対し，分子内および分子間て起きる脱水に対する

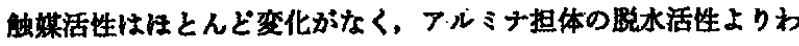
广゙か以上回る程度でする。この傾向は，400 ないし $500^{\circ} \mathrm{C}$ 水素処 理で高温はど蝶葉活性が高くなる 1-ブテンの水秦化ょよび異性 化の扬合と頋向が買なっている。

また，この $15 \% \mathrm{MoO}_{8}-\mathrm{Al}_{2} \mathrm{O}_{8}$ 触媒を水素中 $450^{\circ} \mathrm{C}$ で二疏化能 素の分解反応によって生ずる磄化水菜で 1 時間煺理した触媒につ いても，この反忘を行なった。その結果，全脱水活性怯本来処理 時の 50\% から 40\% K低下しこれに対し，脱办菜は 25.5\%.K 達し，500 $\mathrm{C}$ て办来処理した触媒の 4 倍の高い蚛媒活性を示し

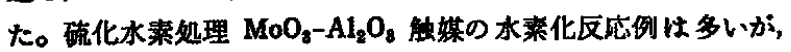
脱水菘反底に対してる触婪活性を示すことが明らかにされた。

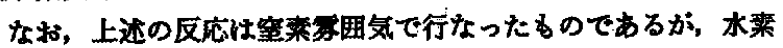

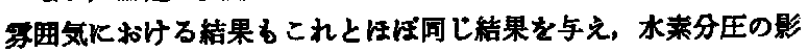
掣がほとんどないことがわかった。

\section{4 考萫}

以上の結果をまとめると，水素処理 $\mathrm{MoO}_{2}-\mathrm{Al}_{2} \mathrm{O}_{3}$ 触 媒では,

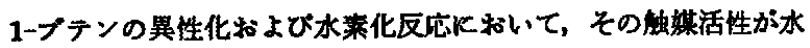
柴処理盓度飞大きく依存し，高温处理すれば両反応とも呼応して 增加することから，これらの活性点がたがい隹連していること

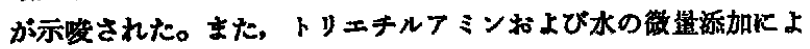
って两反店とも活性が低下することからる，このことが支持され た。しかしながら，2-プテンの水素化（表2）では, 雨活性点が 異なるといら結果になり矛盾する。そこで,これまで報告され た水菜処理 $\mathrm{MoO}_{3}-\mathrm{Al}_{2} \mathrm{O}_{\mathrm{a}}$ 触禁の表面状態润するいくつかの報 告を参照して, 上記のブテンの水秦化および異性化反応と触媒表 面状熊との関保を考えてみる。

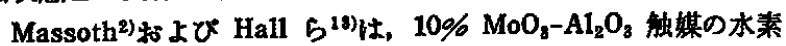

11) K. Tanabe, "Solid Acids and Bases", Kodansha Ltd., Tokyo (1970) p. 122, 141.

12) 0. V. Krylov, "Catalysis by Nonmetals", Academic Press, New York (1970) p. 116.
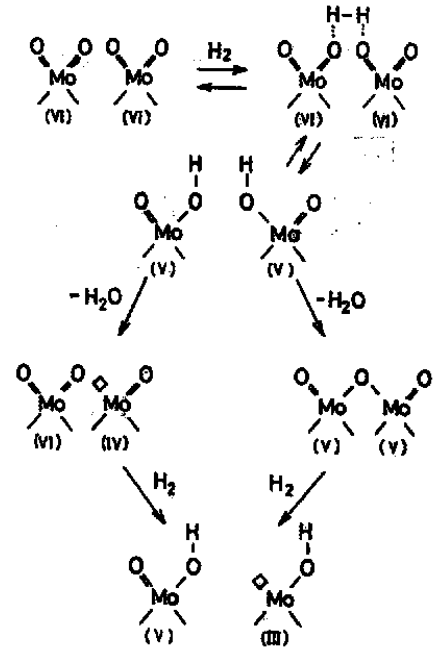

Fig. 5 Reaction mechanism for reduction proposed by Massoth2)

$$
\begin{aligned}
& \text { ( ) : Formal valence } \\
& \square \text { : Anion vacancy }
\end{aligned}
$$

による還元を速度論的および化学量論的に検討し，さらに水素造 元・再酸化サイクルで，本素の可逆がよび不可逆受着量，故出さ

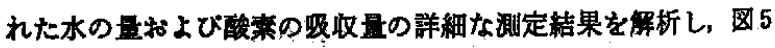
に示される $\mathrm{MOO}_{3}-\mathrm{Al}_{2} \mathrm{O}_{9}$ 触媒の遥元表面モデルを提唱している。 これによれば，フルミナ表面に酸化モリプデン(い)と強い相互作 用をるった単分子層が形成され，水素䗬元によって，この表面に 水素が化学睎着すると考えられている。代学吸着のあと図のより

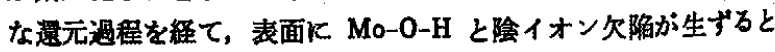
されている。この㓌イオン欠宿は，400から500 処理する注ど多数生成し，これKプテンが配位して氷莱化が進行 すると考えられる。

いま，各ブテン異性体が除イオン欠陥に眍位した場合，その立 体障害を考えると、cis-2-ブテンがすっとも障書が少なく安定な 配位を取り得る。ついで, 1-ブテン, trans-2-ブテンの政であ る。これらの中間体に水素が付加する場合に，その速度はこれら の中間体の安定性と関連し，上の順序と対応があると考えられ る。事実, '巽性体の水索化活性の序列は, trans-2-ブテン>1-ブ テン》cis-2-ブテン で, 上の䏹序と逆に対応し，上速の推定が支

13) W. H. Hall, F. E. Massoth, J.Catal., 34, 41(1974). 
持された。したがって、ブテンは陰イオン欠陷におをらく し，その中間体を経て近接しだ Mo-0-H から水热を受け取りブ タシに，あるい他の異性体火变化すると考えられる。

また，吸着ピリジンの IR 唚取スペクトルの解析から，還元触 煁上 Lewis 酸点就よび Brönsted 酸点が存在することが明ら 加されている(1)16)。山田谷らすは，水素処理によって，フンモ 二フの不可逆吸着量が堌加する事実を隍イオン久陷と関連づけ， これを Lewis 酸に螖属させ，可逆的に樶着する部分を Mo-0$\mathrm{H}^{+}$の Brönsted 酸に対応させている。したがって, これに基つ いてつぎのよらな各中間体が考えられる。

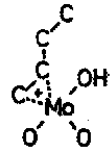

(a)

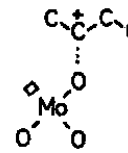

(b)

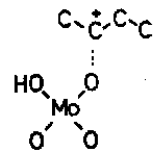

(c)
14) F. E. Kiviat, L. Petrabis, J. Phys. Chem., 72, 1232(1973).

15) T. Fransen, O. van der Meer, P. Mars, ibid., 80, 2103 (1976).
办の加毒実験の結果では, トリエキルフミンより約 8 倍の派加 量にもかかわらず, 1-ブテンの異性化が 3 倍程度速く進行する。 これは，水分子がイオン欠陷作位しても，(c)に示すような中 間体を形成することがてきる新たな酸点が生じるためと推定され る。

硫化水索処理した $\mathrm{MoO}_{8}-\mathrm{Al}_{2} \mathrm{O}_{8}$ 触媒の表面状態について，水 素処理同様飞 Mo-0-H に相当する Mo-S-H とこれk䇟接した イオン久楩が存在すると郝告されている10)。酸素と硫黄の電気㓌 性度を比慗すると Mo-S-H より Mo-O-H の方が分極し, すなわ ち，後者はブロトン酸として，前者は水素原子としてそれぞれ解 離する㑯向火あると思われる。このことは，2-プロパノールの脱

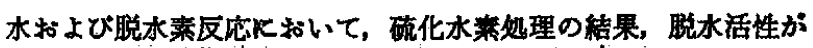
水䇣処理より減少し，脱水菜活性がきわめて高くなった事実とよ く対応している。

本研究は昭和 51 年度文部省科学研宪费福助金 No.011014 で行 なわれた。ここと謝意を丧する。

16) P. Rathasamy, J. J. Fripiat, Trans. Faraday Soc., 66, 2897 (1970).

\author{
Isomerization and Hydrogenation of 1-Butene over $\mathrm{MoO}_{3}-\mathrm{Al}_{2} \mathrm{O}_{3}$ \\ Catalysts Pretreated with Hydrogen

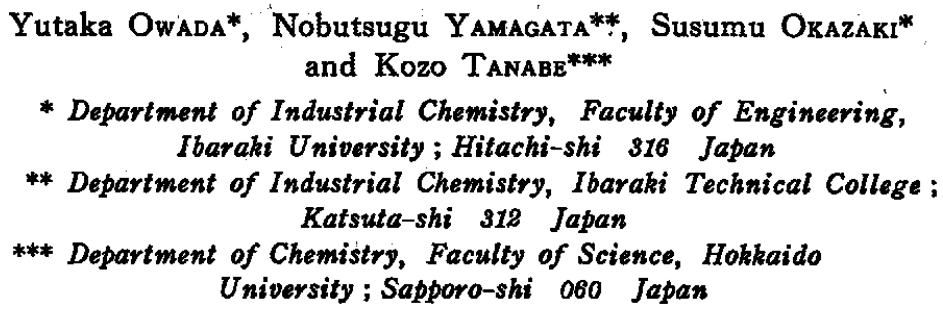

The isomerization and hydrogenation of 1-butene were studied over $\mathrm{MoO}_{8}-\mathrm{Al}_{2} \mathrm{O}_{3}$ catalysts reduced with hydrogen to elucidate the relation between the activity and the acidic property of the catalysts. The catalytic activities for the isomerization and the hydrogenation were remarkably increased by pretreatment with hydrogen above $400^{\circ} \mathrm{C}$ (Fig. 2). The activities were found to be poisoned reversibly with water and irreversibly with triethylamine, but not with carbon dioxide (Fig.4). The increasing catalytic activity for the hydrogenation of butene isomers was in the order cis-2-butene $<1$-butene $<$ trans-2-butene, and the activity for the isomerization was almost in the same order. It is suggested that the active sites serve as electron acceptors and the sites for the isomerization are different from those for the hydrogenation. The dehydration and dehydrogenation of 2-propanol were also studied over $\mathrm{MoO}_{3}-\mathrm{Al}_{2} \mathrm{O}_{8}$ catalysts pretreated with hydrogen or hydrogen sulfide (Table 3 ) and the catalytic activity was discussed in connection with the surface structure of the catalysts. 